\title{
Eteokles in Spain? On Brecht's Mein Bruder war ein Flieger
}

Filippomaria Pontani, $1 \bowtie$

Phone: +390412346349

Email: f.pontani@unive.it

1 Università Ca' Foscari, Dorsoduro 3484/D, 30123 Venice, Italy

\section{Abstract}

One of Bertolt Brecht's most famous poems, Mein Bruder war ein Flieger, is often invoked as a manifesto for pacifist ideals, but some essential questions (who is the lyric I? what is the literal meaning of the poem?) have hardly received any attention. By evoking the poem's nature as a Kinderlied, the context of its first publication, and its relationship with Brecht's play Die Gewehre der Frau Carrar, this article tentatively identifies the source of its final pointe in a famous passage of Aeschylus' Seven against Thebes, thereby suggesting - on the basis of textual comparisons - an example of farreaching, ideological Antikerezeption in Brecht's oeuvre, working all the way down to his Kalendergeschichten and to his Antigone.

\section{Keywords}

Brecht

Aeschylus

Spanish Civil War

War rhetoric

Greek myth

Classical reception

The brother of Bertolt Brecht (Walter Brecht, Augsburg 1900—Darmstadt 
1986) never served in the German army as an aviator; he was a distinguished professor of paper engineering at Darmstadt Technische Universität from 1931 until his retirement 40 years later. This historical evidence ensures that one of Brecht's most famous poems should not be taken ad litteram.

Mein Bruder war ein Flieger

Mein Bruder war ein Flieger

Eines Tags bekam er eine Kart

er hat seine Kiste eingepackt

Und südwärts ging die Fahrt.

Mein Bruder ist ein Eroberer

Unserm Volke fehlt's an Raum

Und Grund und Boden zu kriegen ist

Bei uns ein alter Traum.

Der Raum, den mein Bruder eroberte

Liegt im Quadaramamassiv

Er ist lang einen Meter achtzig

Und einen Meter fünfzig tief. (BFA 12: 22.70.82)

Despite its unceasing popularity as a revolutionary song, or as a manifesto of the international pacifist movement, this text has attracted surprisingly little scholarly attention, perhaps due to its seeming simplicity. ${ }^{1}$ The three obvious questions it raises are: a. who is speaking? b. which military expedition is implied? c. which conquest do the final lines hint to? 
Let us start from point b. The poem was first published on p. 3 of the Sunday supplement of the German newspaper Pariser Tageszeitung on Oct. 17th, 1937: this editio princeps is philologically very close to the definitive version included in Brecht's 1939 Svendborger Gedichte. ${ }^{2}$ The poem appeared on the Paris newspaper, which was one of the most open supporters of the Volksfront (see Huss-Michel 1987, 86), with the following note: "Zu der Pariser Aufführung von Brechts Die Gewehre der Frau Carrar'". Die Gewehre der Frau Carrar, premiered on Oct. 16th in the Salle Adyar (see Hecht 1998, 522), is one of Brecht's most popular plays, staging a family conflict about the armed resistance against the military dictatorship of general Francisco Franco; this state of affairs, together with the mention of the Sierra de Guadarrama in 1. 10 (an important stronghold of Franco's opponents in the struggle of 1936-37), makes sure that the background of Mein Bruder is the Spanish Civil War. More precisely, the protagonist of Mein Bruder appears to be an aviator of the socalled "Legion Condor", i.e. of the military aviation corps sent out by Nazi Germany in the summer of 1936 to help the loyalist troops against the democratic insurrection and the International Brigades. ${ }^{3}$

To be sure, our poem clearly revolves around the conquest of new land: the second strophe, which switches to the present tense, makes abstraction from the personal case of the "Bruder", and projects the higher aim of territorial acquisition against the broader background of the German nation's international politics: Brecht's lines clearly take their cue from the slogans of Nazi propaganda, and particularly from the title of Hans Grimm's 1926 essay Volk ohne Raum (Marsch 1974, 275; see also BFA 12.363). It must be stressed, however, that Hitler's Condor Legion never declared the conquest of Spain as its primary aim, but rather insisted on the preservation of "freedom" and "honour" for a foreign country and an allied government. Perhaps the most uncontroversial document of this attitude is provided by the military songs of the Legion, which all proclaim the need to free Spain from anarchy and from the communist threat, but never even remotely hint to an imperialistic goal. ${ }^{4}$

A further difficulty concerns the first of the three aforementioned questions: since it is clear that the author's brother is not implied, we must assume that a generic "lyric I" is speaking, perhaps in the effort to give a more immediate and spontaneous appearance to the statement. In the Svendborger Gedichte, this 
poem will appear in a section of six Kinderlieder (mostly dating back to 1934), whose very inclusion in the final sylloge made the object of lively discussions between Brecht and Walter Benjamin, with the latter arguing against this opportunity, and Brecht retorting that "nursery rhymes" were to be included because Nazi propaganda had to be challenged since the earliest stages of children's education. ${ }^{5}$ The general tone of the Kinderlieder (including the Gottsbeiuns, where only a generic "Kanzler", not Hitler's name, is mentioned) reminds one of medieval tales and allegorical rhymed fables rather than of sheer political polemic. In our specific case, the idea of having a generic vox veritatis speak in a naif tone about the illusions and the sad fate of a German aviator may indeed be effective: the simple words of a child, who at first acritically and perhaps admiratively buys into the slogans of the Nazi propaganda applying them to the biography of his (clearly elder) brother (a "kindliche Darstellung": Pinkert 1988, 106), are allyeventually perverted so as to produce an overt demystification of the regime's rhetoric. ${ }^{6}$ But is this the only reason for choosing a "brother" as the poem's protagonist?

One should recall that Mein Bruder implies a reference not only to conquest war in general terms, but to Spain's civil conflict - which is after all, like all civil wars, a conflict between "brothers" - , and more specifically to the Spaltung of the German nation between the aviators and soldiers supporting the Spanish loyalists on the one side, and the revolutionaries who were fighting in the International Brigades on the other. ${ }^{7}$ We should thus probably stress the connection of this poem, on the one hand, with Brecht's view of the Spanish war as a symptom of the fascist wave that had already led to civil unrests and dire political consequences in Germany and Italy, ${ }^{8}$ and on the other hand with the aforementioned Gewehre der Frau Carrar. This play-dominated by family relationships (between the protagonist and her brother, who is fighting in the resistants' army; between Frau Carrar's two sons, whom she tries to prevent from taking an active part in the war; between Frau Pérez's son and daughter, who have fought on opposite fronts $)^{9}$ — was written for a troupe of German émigrés in Paris and staged under the auspices of the German opposition in the French capital. ${ }^{10}$ Nor should we forget that on June 18th, 1937, Brecht had been asked by the Madrid-based radio "Deutscher Freiheitssender" to write something for them (see Hecht 1998, 512) - one may wonder if our poem arose out of that eommandcommission? 
Mein Bruder has been singled out as an outstanding example of the poetic typology known as "erzählendes Pointengedicht" (see Graefe 1972, 57-58): the final strophe implies an alienating opposition between the size of the targeted land and that of the conqueror's tomb, and it is clearly designed to unmask the crude reality behind the pompous "Blut und Boden" rhetoric of the Third Reich (see Crick 2000) - a mechanism that inspires other Svendborger Gedichte as well (see Jeske 20022001,341 ) and that reminds one of some visual material collected by Brecht in the Kriegsfibel. ${ }^{11}$ Since this grimly ironic opposition between the two images of Raum is the real barycenter of the entire poem, it may be worth asking whether it must be regarded as Brecht's own invention. To the best of my knowledge, the only critic who has attempted to answer this question is E.-U. Pinkert, who has pointed to a similar contrast between the size of man's greed and his real, ephemeral dimension in Lev Tolstoj's tale How much land does a man need (1885). ${ }^{12}$ While certainly subtle and learned, this suggestion obliterates the fact that the main character of Tolstoj's tale is a simple peasant who stupidly attempts to enlarge his own fortune, only to die in the process (and thus ebtainingobtains for himself only the land occupied by his own grave): this personal greed is in no way connected to a war or to a national or collective enterprise.

AQ1

There is, however, another literary text that insists precisely on the opposition between the grand ambition of military conquest and the much humbler reality of a soldier's burial: Aeschylus' tragedy Seven against Thebes (467 BCE) stages the conflict between Oedipus' sons Eteokles and Polyneikes, the former being the ruler of Thebes, the latter defending his right to the throne (in his view, usurped by Eteokles) by means of a military expedition of troops gathered from the city of Argos. The war is eventually decided by a series of seven duels (one Theban hero against one Argive hero), each taking place at one of the city's seven gates; while the Thebans triumph in all other confrontations, the duel opposing Eteokles and Polyneikes ends in a mutual killing, announced on stage by a herald in the following terms (11. 816-19):

the leaders, the two generals, have divided

the whole of their property with hammered Scythian steel. 
They will possess only that land they take in burial,

swept away as they were in accordance with their father's curses [transl. H. Weir Smyth].

The German translation of the aforementioned lines by Gustav Droysen runs as follows (11. 798-801): ${ }^{13}$

Die beiden Feldherrn theilten mit dem Skythischen

Gestählten Eisen ihres Reichs Gesammtbesitz;

Wie viel ein Grab deckt, bleibt des Landes denen noch,

Die durch des Vaters argen Fluch erschlagen sind. ${ }^{14}$

The herald's announcement, by referring to the sad outcome of the duel, openly bewails the calamity that has befallen Thebes even in this moment of "victory" against the Argive invaders: this statement implicitly sheds light on the insanity of both brothers' longing for a land that they will now only "own" as dead corpses. The theme of land-division and land-ownership is recurrent in Aeschylus' plays, and particularly in the Seven against Thebes: ${ }^{15}$ suffice it to recall, with the herald and the chorus (11. 730-33), ${ }^{16}$ Oedipus' curse on Eteokles and Polyneikes that they might obtain as much land as occupied by their graves.

The idea of conquest war (victorious though it may be) as leading to the conquest of a grave, is manifestly the same in Mein Bruder and in the Seven Against Thebes. We know that in the case of analogies between Brecht's works and classical literature, the temptation to establish a direct connection must be treated with caution, ${ }^{17}$ despite the undeniable fact that Brecht- - who had no first-hand training in Greek-made a remarkable use of ancient material throughout his career, and remains the key author for the reception of Greek and Latin literature in German Marxist literature before and after the war. ${ }^{18}$ In the present case, however, I believe there is a certain probability that Brecht was in fact inspired by Aeschylus' lines_-not only in view of the well-known fact that he had expressed his anti-militarist stance in Classical garb as early as 1916, 
with a scandalous school essay on Horace's Dulce et decorum pro patria mori (Hohenwallner 2004, 12-16 and 32-37).

First of all, a copy of Droysen's translation of Aeschylus belonged to Brecht's library (and most probably figured among the books he took with himself in the Danish exile): it can still be found in the Bertolt-Brecht-Archiv on the Chausseestrasse, where it bears the shelfmark "G 02/016". ${ }^{19}$ Brecht's hand drew a pencil stroke on the margin of a passage of Droysen's introduction to Aeschylus' Prometheus on p. 376 (just 20 pages away from the aforementioned lines of the Seven); whether this sign of attention dates back to the earliest stages of Brecht's interest for the character of Prometheus (i.e. the times around 1920 , when the poem by the same title was composed $)^{20}$ or to a later period in his life, is of course hard to tell.

Aeschylus occurs more than once in the corpus of Brecht's writings: when, in a note of 1940-41, Brecht describes Aeschylus' world as "full of battle and dread", it is hard not to think of Gorgias' judgment on the Seven against Thebes as a play "full of Ares" (fr. 24 Diels-Kranz = Plutarch, Table Talk 715e). ${ }^{21}$ It would also be interesting to explore more in detail the Greek, and especially Aeschylean, facies of Die Gewehre der Frau Carrar, a play staging family ties, women's resistance to war, and the ineluctability of fate-a play the author himself once described as pure "aristotelische (Einfühlungs-) Dramatik". 22

More importantly, the spurious finale of Aeschylus' Seven, which in its current form might be the fruit of a later reworking by an anonymous author of the 4th c. $\mathrm{BCE},{ }^{23}$ deals with a mythical quarrel that will be of paramount importance to Brecht. In fact, the final scene (11. 1005-78) stages a lively discussion between Antigone and a herald about the burial denied to Polyneikes' corpse, an issue that is totally foreign to the body of Aeschylus' play and looks ahead to the one ancient tragedy expressly devoted to this story, namely the Antigone of Sophocles, which Brecht will notoriously rework —also through Hölderlin's mediation-in 1948-50 (Die Antigone des Sophokles). Both Brecht's and Sophocles' Antigones start precisely from the denial of a soldier's grave- the same grave whose "conquest" is evoked in the last strophe of Mein Bruder.

But there are also two further clues that could point to a "Theban" prehistory for Mein Bruder: first of all, the third section of the Svendborger Gedichte 
(Chroniken) opens with the famous 1934 poem Fragen eines lesenden Arbeiters, whose first line reads "Wer baute das siebentorige Theben?". This might of course be merely the fruit of chance, but a common ground between our poem and the Fragen is represented by the impulse to unmask the negative effects of power on the lower classes (i.e. both when the state rulers plan ambitious wars and when they design grand monuments: in the Fragen these two aspects are explicitly and closely interwoven) (Hohenwallner 2004, 12428 ). Indeed, the issue of power, its misdemeanours and its potentially dire consequences on the poor, finds a Paradebeispiel in the misuse of technology: the reference to aviation in Mein Bruder is a hint to the unjustifiable corruption of man's eternal dream to fly (one need just think of the other famous Kinderlied, Ulm 1592, on the tailor who wanted to fly) (Kittstein 2012, 276; H. Kaulen, in: $\mathrm{BH}^{{ }^{2}}{ }_{\text {-Kaulen }} 2001,263$ ). That airplanes should be used in order to kill and destroy - almost a novelty in the first global war in which mass destruction of civilians came from the air-means that the progress of mankind is being perverted to dreadful ends: precisely this polemical hint will be picked up in Heiner Müller's tribute to Mein Bruder, the Traktoristenliedchen, which re-writes Brecht's poem by contrasting (in 1956!) the tanks of fascist imperialism with the tractors of socialist states (Ebrecht 2001, 45-47).

A final clue. Mein Bruder will be reused by Brecht in his Kalendergeschichten (published in 1948/49): it will be the only Kinderlied to receive this honour together with Ulm 1592, and one of seven pieces from the Svendborger Gedichte (the preceding one being precisely the Fragen eines lesenden Arbeiters). Scholars have been debating for decades on the exact meaning of this collection of prose and verse, in terms of genre and overall meaning, as well as on the order of its various pieces. ${ }^{24}$ While it would be idle to tackle here this thorny issue, what is certain is that in that collection Mein Bruder follows immediately upon the long tale Der verwundete Sokrates (1938), which stages the Athenian philosopher after the battle of Delion (fought in $424 \mathrm{BCE}$ ), reacting in a honest manner to an undeserved fame of military prowess (see Witzmann 1965, 50-51). If we accept my proposal of a "Greek" intertext to the poem, the connection between Socrates' Geschichte and Mein Bruder is immediately established, not only on the ideological niveau, ${ }^{25}$ but also because both pieces involve the de-mystification of a typically Greek model of military arete. 
But there may be more to this: as an orthodox Marxist, Brecht was particularly sensitive to the theme of human greed as the true reason for conflicts. Now, this theme surfaces in several of the texts we have evoked, featuring prominently in Aeschylus' Seven as the prime reason of the quarrel between Eteokles and Polyneikes (a quarrel that ended up in both brothers' destruction and death), as well as in Mein Bruder war ein Flieger, where a war primarily directed to give assistance to the Spanish regime is presented as a war that actually aims to conquer new land. ${ }^{26}$ The same motif may lie behind Brecht's decision to transform - by means of a heavy anachronism - the battle of Delion from what it was-a conflict between Athens and Thebes, in the frame of the Peloponnesian War (a civil war, in its own way) - into a battle opposing two competing nations, Athenians and Persians. ${ }^{27}$ Finally, and more importantly, this is also the rationale behind Brecht's literary re-writing of Sophocles' (and Hölderlin's) Antigone, for Brecht's Eteokles and Polyneikes do not kill each other, but both fight in the same army and in the same conquest war against Argos, simply displaying a different attitude towards war: Eteokles dies at war, whereas Polyneikes - seeing the death of his brother and finding no justification for this dirty conflict — deserts the army and is therefore sentenced to death. ${ }^{28}$

If we accept the idea that the pointe in Mein Bruder has its most obvious predecessor in Aeschylus' Seven against Thebes, why not consider the aviator in Brecht's poem as an alter ego of Eteokles? All these elements and texts ultimately converge: conquest war is presented as a deplorable and hypocrit mechanism to which power inevitably resorts when inner conflicts become impossible to handle; the reality behind war propaganda is in fact bitter disappointment and ainpointless death; resistance against the violence of an unjustified conquest war is presented as a moral duty that must transcend, indeed sometimes even contradict family ties.

\section{Abbreviations}

$\mathrm{BBA}=$ Bertolt-Brecht-Archiv, Chausseestr. 125, Berlin.

BFA = Hecht, W., J. Knopf, W. Mittenzwei und K.-D. Müller (eds.), Große Kommentierte Berliner und Frankfurter Ausgabe, 30 vols., Frankfurt/Main: Suhrkamp, 1988-2000. 
BH=Knopf, J. (ed.), Breeht-Hantbuch, 5 vols., Stutgart: Metzler, 2001-2003.

\section{References}

Bazing, E. (2001). Internationale Lyrik zum Spanischen Bürgerkrieg (193639). St. Ingbert: Roehrig.

Bohnen, K. (1967). Brechts Gewehre der Frau Carrar. Frankfurt/Main: Surhkamp.

Crick, J. (2000). The fourth door. In R. Speirs (Ed.), Brecht's poetry of political exile (pp. 114-134). Cambrigde: CUP.

Droysen, J. G. (1868). Aischylos, übersetzt von J.G.D. (III ed.). Berlin: Hertz.

Ebrecht, K. (2001). Heiner Müllers Lyrik: Quellen und Vorbilder. Würzburg: Koenigshausen \& Neumann.

Graefe, H. (1972). Das deutsche Erzählgedicht im 20. Jahrhundert. Frankfurt/Main: Thesen.

Groeneboom, P. (1938). Aeschylus'Zeven tegen Thebe. Groningen: Wolters.

Hasselbach, I. K. (1990). Bertolt Brecht. Kalendergeschichten. München: Oldenbourg.

Hecht, W. (1965). Bertolt Brecht. Die Antigone des Sophokles. Materialien zur Antigone. Frankfurt/Main: Suhrkamp.

Hecht, W. (1998). Brecht Chronik 1898-1956. Frankfurt/Main: Suhrkamp.

Hohenwallner, I. (2004). Antikerezeption in den Gedichten Bertolt Brechts. Paderborn: Bibliopolis. 
Huss-Michel, A. (1987). Literarische und politische Zeitschriften des Exils 1933-1945. Stuttgart: Metzler.

Hutchinson, G. O. (1985). Aeschylus. The seven against Thebes. Oxford: OUP.

Ignasiak, D. (1982). Bertolt Brechts Kalendergeschichten. Berlin: BrechtZentrum der DDR.

Jeske, W. (2001). Svendborger Gedichte. In J. Knopf (Ed.), BrechtHandbuch, vol. 2 (pp. 325-42). Stuttgart: Metzler.

Kittstein, U. (2012). Das lyrische Werk Bertolt Brechts. Stuttgart: Metzler.

Knopf, J. (1980). Die Gewehre der Frau Carrar. In J. Knopf (Ed.), BrechtHandbuch. Theater (pp. 150-157). Stuttgart: Metzler.

Knopf, J. (2002). Kalendergeschichten. In J. Knopf (Ed.), BrechtHandbuch, vol. 3 (pp. 403-16). Stuttgart: Metzler. AQ2

Kratzmeier, D. (2013). Bertolt Brecht, Kalendergeschichten. Frankfurt/Main: Suhrkamp.

Lausberg, M. (1999). Brechts Lyrik und die Antike. In H. Koopmann (Ed.), Brechts Lyrik-neue Deutungen (pp. 163-198). Würzburg: Koenigshausen \& Neumann.

Lupas, L., \& Petre, Z. (1981). Commentaire aux Sept contre Thèbes d'Eschyle. Bucarest-Paris: Editura Academiei-Les Belles Lettres.

Marsch, E. (1974). Brecht-Kommentar zum lyrischen Werk. München: Winkler.

Müller, K.-D. (1980). Brecht-Kommentar zur erzählenden Prosa. München: 
Winkler.

Phleps, Th. (2013). Der müde Soldat. In S. Hahnheide et al. (Eds.), Musik bezieht Stellung (pp. 403-427). Osnabrück-Göttingen: Vandenhoeck \& Rupprecht.

Pinkert, E.-U. (1988). Brechts Kinderlieder und das Volksvermögen. In W. Wucherpfennig \& K. Schulte (Eds.), Bertolt Brecht-Die Widersprüche sind die Hoffnungen (pp. 103-129). München: W. Fink.

Ramthun, H. (1970). Bertolt-Brecht-Archiv: Bestandsverzeichnis II. BerlinWeimar: Aufbau.

Revermann, M. (2016). Brecht and Greek tragedy: Re-thinking the dialectics of utilising the tradition of theatre. German Life and Letters, 69, 213-232.

Roth, A. (1993). Das nationalsozialistische Massenlied. Würzburg: Koenigshausen \& Neumann.

Seaford, R. (2012). Cosmology and the polis. Cambridge: CUP.

Seidensticker, B. (1992). The political use of antiquity in the literature of the German democratic republic. Illinois Classical Studies, 17, 347-367.

Thalmann, W. G. (1978). Dramatic art in Aeschylus'Seven against Thebes. New Haven-London: Yale University Press.

Wagner, F. D. (2002). Der verwundete Sokrates. In J. Knopf (Ed.), BrechtHandbuch, vol. 3 (pp. 313-19). Stuttgart: Metzler.

Weiss, P. (1978). Die Ästhetik des Widerstandes. II. Frankfurt/Main: Suhrkamp. 
Werner, J. (1978). Der Fall Sokrates. Klio, 60, 593-610.

Whitaker, P. (1985). Brecht's poetry. Oxford: OUP.

Witzmann, P. (1965). Antike Tradition im Werk Bertolt Brechts. Berlin: Akademie.

Wizisla, E., Streidt, H., \& Loeper, H. (2007). Die Bibliothek Bertolt Brechts. Frankfurt/Main: Suhrkamp.

1 A good analysis of its rhetorical structure in Bazing (2001, 28-33).

2 The only meaningful variants of the 1937 princeps are "war" rather than "ist" in 11.5 and 7 (with "Guadaramamassiv" in 1.10), and above all the title Mein Bruder, der Flieger, to be compared with the title Mein Bruder, der Eroberer penned by Brecht as a variant in the proof copy of the early Svendborger Gedichte once owned by Ruth Berlau, BBA 1971/39 (the other autograph corrections in this copy did find their way into the final edition; I have checked the versions 8786-8790 listed in Ramthun 1970, 410-11). Few minor variants appear in the version that served as a basis for Hanns Eisler's musical rendering of August 1937 (under the title Spanisches Liedchen): see the "Mappe Eisler" (BBA 1251/27), and Phleps (2013, 412-14). 3 According to BFA 12.363 (see also Kratzmeier 2013, 196) the poem was actually written in 1937, possibly after the famous German attack on Guernica on April 26th.

4 See Roth (1993, 187-90). One may wonder if some Stichwörter and the rhythm of the short lines (especially the remarkably scanned third strophe: Bazing 2001, 32), might have been present to Brecht: it is particularly noteworthy_in opposition to strophe 1 of Mein Bruderthat the official "Legionslied" (Roth 1993, 190) presents the fighters as volunteers rather than conscribed soldiers: “Als freie Kämpfer wir uns fanden, / wir zogen aus das graue Kleid...”. 5 See Hecht (1998, 547): Brecht had sent Benjamin some Kinderlieder as early as July 1937 , which makes it very likely that Mein Bruder had already been written by that time (Kittstein 2012, 271-72; Jeske 2001, 333).

${ }^{6}$ On this aspect of the Svendborger Gedichte (very evident, e.g., in the famous epigram of the Deutsche Kriegsfibel: “Die Oberen sagen:/Es geht in den Ruhm./Die Unteren sagen:/Es geht ins Grab") see Whitaker $(1985,124-25)$.

7 Marsch (1974, 276): "Brechts Bruder Walter ist in diesem Gedicht sicher nicht gemeint, vielmehr die Deutschen insgesamt, die auf beiden Seiten, in Brigaden der linken Volksfrontregierung (Internationale Brigaden) und der Falange General Francos (Legion 
Condor), gegeneinander kämpften”. See also Hasselbach (1990, 64-65); Bazing (2001, 29).

${ }^{8}$ His speech at the 2nd International Writers' Congress in Paris (16-17 July 1937: BFA 22, 323-24; Bohnen 1967, 72-74) ends on an equation between the Italian "Flugzeuggeschwader, die sich auf das unglückliche Abessinien gestürzt hatten" and the German airplanes directed against Spain: two acts of the same imperialistic logic.

9 The newspapers - above all the Danish Politiken, for which see Bohnen (1967, 59-69, esp. 62-63) - reported at length on the sad stories of family antagonisms during the civil war.

10 See Knopf (1980, 150-51); BFA 24, 225; Hecht (1998, 522). For a strong political reading of the play see the review on p. 5 of the same Pariser Tageszeitung of Oct. 17th, 1937.

11 See Kriegsfibel nos. 36 (a German soldier fallen upside down in the Libyan soil) and no. 52 (soldiers sleeping in cavities ofin the ground).

12 Pinkert $(1988,126)$, with the words of caution in note 36.

13 Droysen $(1868,353-54)$. It should be stressed that this translation is profoundly different from that of the first edition (1842).

14 Droysen gives due emphasis to the partitive genitive $\chi \theta$ ovó $\varsigma$, which makes for a complicated syntax (Groeneboom 1938, 225), and has been suspected by several scholars (Brunck's correction into $\chi \theta$ óv $\alpha$ - a reading also found in a single medieviatmedieval manuscript — has been adopted by Hermann, Blomfield, Wecklein, Paley, Hutchinson).

15 See Seaford (2012, 171); Thalmann (1978, 47 and 75-76). By contrast, Hutchinson (1985, xxiiii) insists on patriotism as the Thebans' motivation.

16 In Droysen's translation (373, 11. 711-15): “'s ist scharfschneidiger Stahl, welcher ihr Land / blutig vertheilt, jedem wieviel ihm/Fallend zum Grabe genügt,/Seines, des größeren Reichs verarmet”. See Lupas-Petre $(1981,252)$.

17 See Lausberg $(1999,189)$. On Brecht's selective literary memory see Wizisla et al. (2007, 13-16).

18 See Seidensticker (1992, 350): "There is not a single area of Brecht's rich literary production, from lyric poetry to drama and literary and theoretical prose, that does not show the impact of his study of the ancient world". Witzmann (1965, 15-22). For a theoretical reflection see Hohenwallner (2004, 1-10). Specifically on Brecht's approaches to Greek tragedy see now Revermann (2016).

19 See Wizisla et al. (2007, 292 no. 2166). It should be stressed that not many Greek classics of Brecht's library are actually annotated by him (apart from the Iliad and Plutarch's Lives, I point to the Greek Anthology and to Aristotle's Poetics and Politics). Surprisingly, Aeschylus is not mentioned (nor is any dramatic author) among Brecht's books in the interesting reconstruction of his Svendborg library by Weiss (1978, 311-19).

20 See Hohenwallner $(2004,46-50)$. Witzmann $(1965,39)$. The underlined passage stresses the 
analogy established by Droysen between the myth of Prometheus and some myths of succession in Semitic cultures.

21 BFA 22/2, 613-14: "Die Welt des Aischylos, was immer die Universitäten von harmonieHarmonie murmeln mögen, war erfüllt mit Kampf und Schrecken”. See also a reference to Aeschylus' exclamations of sorrow in the Reisen des Glückgotts (1940-43) in BFA 10/1, 89.5 and 10/2, 930.31: "Seid Künstler, Sterbende!/Mit dem äschileischen Schrei/Glückt es vielleicht".

22 See Bohnen $(1967,97)$, and Knopf (1980, 152-53) for the "Greek" simplicity of the play and of its immediate predecessor, J.M. Synge's Riders to the Sea.

23 Since the nineteenth century (Bergk, Wilamowitz; but already Droysen, who did not accept the lines after 926) scholars believe that Aeschylus' genuine original text ends on 1. 860, and that what follows has either been tampered with or (esp. after 1. 1005) entirely added a posteriori.

24 Müller (1980). Ignasiak (1982, esp. 209-10) for a more elaborate (and debatable) ordering. See most recently Kratzmeier (2013, 163-68).

25 Knopf (2002, 409-10 and 413). Both the Socrates piece and Mein Bruder question the effect of conquest wars on the "kleine Leute", and come to a negativepessimistic conclusion.

26 It should be remarked that Brecht does not use this model when presenting the Spanish civil war in Die Gewehre der Frau Carrar: Bohnen (1967, 191-93).

27 See Ignasiak $(1982,85)$ : “Die Geschichte profitiert aber davon, daß es sich bei Brecht nicht um einen Bürgerkrieg handelt, sondern um einen Krieg, den zwei verschiedene Völker ökonomischer Vorteile wegen führen". In 1955, Brecht tentatively explained this choice as a lapsus memoriae: Werner (1978, 599-601); Wagner (2002, 314).

28 See the opening of the Antigone, 11. 8-12 "Und, jünger als er, Polyneikes/Sieht den Bruder zerstampft unterm Gäulehuf. Weinend/Reitet er aus unfertiger Schlacht, denn anderes andrem/Bescheidet der Schlachtgeist, wenn der hart/Anregend einem mit dem Rechten die Hand erschüttert"; see also Antigone's stubborn distinction between the war for Kreon and that for Thebes in 11. 400-418. Cp. Witzmann (1965, 75-100, esp. 82); and Brecht's note on the real reasons of war and violence in Hecht $(1965,111-12)$. 